International Review of Research in Open and Distributed Learning Volume 18, Number 7

November - 2017

\title{
Faculty Perception of Openness and Attitude to Open Sharing at the Indian National Open University
}

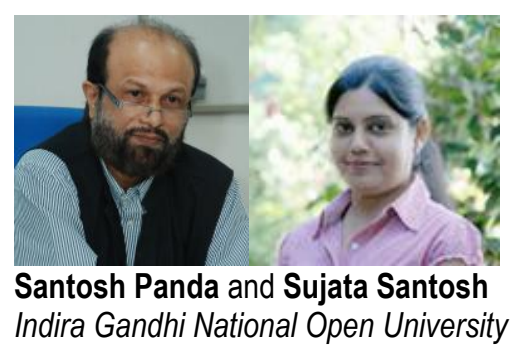

\begin{abstract}
In the past decade, the educational scenario world over has significantly been impacted by open access and open education movements. The philosophy of openness and sharing forms the cornerstone of the open education movement. The distance education approaches, together with open educational resources (OER) and massive open online courses (MOOCs), are being used to serve the increasing educational needs of diverse communities. However, adoption of openness as a core value and as part of the institutional strategy still remains a challenge for academic institutions in general, and distance education institutions in particular, in developing countries like India. In this research study, the authors report an analysis of the perception of the faculty of the Indira Gandhi National Open University of India (IGNOU) about openness and their attitude towards sharing of resources in academic institutions. Data was collected through a structured questionnaire administered to the teachers and academics of IGNOU $(\mathrm{N}=69)$. The results indicated that: the faculty members valued sharing of resources in academic institutions; learning resources should be made available free of cost; there is a strong need for training on intellectual property rights, copyright, and creation and use of OER; and there should be an institutional policy on OER for its effective use.
\end{abstract}

Keywords: openness, open sharing, faculty perception and attitude, Open University, distance education

\section{Introduction}

The Open Access and Open Education movements are gradually reshaping the educational landscape worldwide. Open philosophies call for unrestricted access to knowledge and educational resources and 
diminishing of barriers to education. The basic premises on which the open education movement is based postulate that knowledge should be free and open to use and re-use; that collaboration should be easier; that people should receive credit for contributing to education and research (Baraniuk, 2008). There is growing interest towards fostering of open practices of teaching and learning with a view to leverage education and lifelong learning for the knowledge economy and society (Geser, 2007). Weller (2011) refers to open education "as a response to, or at least as part of, a broader social change made possible by digital technologies" (p. 24). Openness and sharing are the basic principles of the open education movement. Adoption of openness as a core value and as part of institutional strategy, along with tremendous stress on sharing and collaboration, has become crucial for academic institutions to enhance the quality and outreach. The open and distance learning (ODL) system has played a crucial role in widening access to education in many countries. The ODL approaches are in keeping with the ideology of access and availability of knowledge at the doorsteps of the learners. Digital technologies, coupled with OER, could enable distance education institutions to serve the educational needs of diverse communities, provided the learners have easy access to open technologies. ODL institutions are also gradually gearing up to revisit open policies to maintain their competitive edge. In a developing country like India, there are a number of institutions which still continue to function under traditional academic practices, resisting the change towards a culture of openness. Perception and /or attitude play a crucial role in adopting this inevitable change in academic practices. The present paper analyzes the faculty perception about openness and attitude of faculty towards sharing resources at the National Open University in India. The study also aimed to highlight various issues related to sharing of knowledge and learning resources in open and distance learning (ODL) institutions generally. The findings could be useful to both the campusbased and distance teaching universities in reforming their teaching-learning practices.

\section{Literature Review}

\section{Understanding Openness}

Openness in education has been defined as an emerging paradigm of social production in the global knowledge economy (Peters, 2008). Wiley (2006) considers openness as an emerging academic culture stemming from the Open Source Software movement. Yuan, MacNeill, and Kraan (2008) mention that the concept of openness is based on the idea that knowledge should be disseminated and shared freely through the internet for the benefit of society as a whole. The term refers to a kind of transparency in terms of access to information, especially within organizations, institutions, or societies (UNESCO, 2014). In the present decade, openness has emerged as a technological, social, economic, and cultural phenomenon (Peter \& Deimann, 2013). Peters (2008) opines that openness in education embodies democratic values such as freedom, equality, and creativity. As mentioned by Wiley and Hilton III (2009), "Openness is a fundamental value underlying significant changes in society and is a prerequisite to the changes institutions of higher education need to make in order to remain relevant to the society in which they exist” (p. 1). Openness has different meanings and forms depending on the context - which could be social, technical (Tuomi, 2006), organizational (Tapscott \& Ticoll, 2003) or educational (Hylen, 2006). The term "openness" is evolving and encompasses open sources, open educational resources, open courses, open research, open data, and open application program interfaces (APIs) (Weller, 2012). The 
concept of openness can be applied to institutions as well as to information and processes (Committee for Economic Development, 2009). Wiley and Hilton III (2009) argue that every educational institution must address "openness as a core organizational value if it desires to both remain relevant to its learners and to contribute to the positive advancement of the field of higher education”(p. 1).

\section{Openness and Sharing in the Context of Education}

According to Wiley and Green (2012), "education is, first and foremost, an enterprise of sharing" (p. 81). Sharing and openness are altruistic arguments that are in line with academic traditions (McNamara, 2012). The emerging open education movement combines the established academic tradition of sharing and the collaborative and interactive culture of the Internet (Peters, 2008). As mentioned by Cheng (2013), "the idea of openness in education predates late 1910, where it was determined that education should be open" (p. 57). It was in the 1960s and 70s that open education began as a reform project to liberate education from any kind of oppression (Deimann \& Sloep, 2013). The establishment of the United Kingdom Open University (UKOU) in 1969 brought to spotlight the role of openness in higher education (Lane, 2009). The first Chancellor of UKOU, Lord Crowther (as cited in Daniel, 2007) delineated dimensions of openness when he declared the Open University "open as to people, open as to places, open as to methods, and finally open as to ideas" (p. 3), with the aim to widen access to higher education. This has formed the cornerstone of openness in higher education across the world with "the common belief in the power of education to transform lives, communities and nations” (Olcott, 2013, p. 16).

The open education movement calls for "unrestricted access to educational materials and diminishing of geographic and economic barriers to participation" (Knox, 2013a, p. 21). Tuomi (2006) distinguishes three areas where openness is perceived to make a difference in education: technical characteristics, social characteristics, and the nature of the resources. Openness in the social domain is fundamentally motivated by the expected social benefits and by ethical considerations related to the freedom to use, contribution, and sharing. Openness in the technical domain, in contrast, is characterized by technical interoperability and functionality. The paradigm of openness in higher education provides opportunities for sharing of ideas, collaboration among institutions, educators, and learners locally and internationally, thus facilitating more meaningful engagement in teaching and learning (Yuan \& Powell, 2013). Openness in education, thus involves systems and processes which are more transparent in nature, provide accredited qualification and skills to the learners so that they may be gainfully employed and contribute to the economic growth of the state (Mishra, 2012).

Several researchers (Bayne, Knox \& Ross, 2015; Edwards, 2015; Moe, 2015; McNamara, 2012; Olcott, 2013) have discussed the idea of openness in educational practices through varied perspectives. The notion of openness is related to: access and choice (as exemplified in the context of open universities); no cost or low-cost access (as in the context of OER); and being freely available (as in the context of open access) (Jones, 2015). The idea that knowledge is a public good is closely aligned to unfettered access to educational opportunities and the demolishing of established barriers to education (Torres, 2013). Openness in education seeks to bring about a more equitable educational future by expanding access to learning for everyone, especially for the non-traditional learners and marginalized sections of the society (Oliver, 2015; Olakulehin \& Singh, 2013). 


\section{Openness, Sharing, and the OER Movement}

Open Education Resources (OER), followed by Massive Open Online Courses (MOOCs), form an important part of openness in education. The beginning of the OER movement was marked by the OpenCourseWare (OCW) initiative by the Massachusetts Institute of Technology (MIT), in the year 2001. In the UNESCO forum on the potential of open courseware for higher education in the developing countries V.S. Prasad (UNESCO, 2002a) from India mentioned that "the Open Courseware concept is based on the philosophical view of knowledge as a collective social product and so it is also desirable to make it a social property" (p. 15).

As the OER movement spread across the world, the definition of OER also expanded to embrace the characteristics of open license and knowledge sharing, and to include course materials, modules, textbooks, streaming videos, tests, software, and any other tools, materials, or techniques used to support access to knowledge (Chen \& Panda, 2013). The OER movement is characterized by sharing and reuse (Pegler, 2012). The Cape Town Open Education Declaration (2007) propelled educators, learners, and organizations to pursue additional strategies in open educational technology, open sharing of teaching practices and other approaches that promote open education. The rapid growth of OER, enabled by open licensing and new digital technologies, provides new opportunities for teaching and learning, and at the same time, challenges established views about teaching and learning practices in higher education (Yuan et al., 2008).

Previous research studies have largely discussed openness in the context of OER (Rolfe, 2012; Butcher, 2011; Iiyoshi \&Vijay Kumar, 2008; Wiley \& Hilton III, 2009; Downes, 2007, Hylén, 2006). Walker (as cited in Downes, 2007) defines open as "convenient, effective, affordable, and sustainable and available to every learner and teacher worldwide" (p. 2). According to Hylén (2006), the two most important aspects of openness have to do with free availability over the Internet and as few restrictions as possible on the use of the resources. Schaffert and Geser (2008) identified four key attributes in the context of the concept of openness in OER - open access, open license, open format, and open software. Dalsgaard and Thestrup (2015) provided three pedagogical approaches to openness as transparency, communication, and engagement. Wiley (2009) proposed $4 \mathrm{R}$ framework to measure the openness of content in terms of the rights granted to the user of the content - reuse, revise, remix, redistribute (Wiley, 2009). He further expanded this to include the $5^{\text {th }}$ dimension of openness - retain, which pertains to the right to create and own copies of the content (Wiley, 2014). Ehlers (2011) presented a model which conceptualized three degrees of openness - low, medium and high. Hodgkinson-Williams and Gray (2009) described four key attributes in terms of social, technical, legal, and financial openness. Wiley and Hilton III (2009) identified key areas for educational transformation as connectedness, personalization, participation, and openness. They noted that a culture of openness in higher education is a critical prerequisite to large-scale progress in the other three areas. Conole (2010) argued that OEPs, which are activities and support around the creation and use of OER in the form of guidelines, policy, and broader management, are critical for leveraging OER effectively. Downes (2007) mentioned that most of OER initiatives offer a most basic level of openness, where open means "without cost" but not "without conditions" (p. 32). Olcott (2012) underlined that there is a need for imposing more structures in educational institutions to expand openness. This critical literature suggests a fair degree of clarity in the framework and practice of openness in teaching-learning today. 
"Sharing" forms a key concept in the discussion on open education, OER, and in the context of Web 2.0 technologies. As mentioned by Hug (2014), notions of sharing play a crucial role in the open content and open education strategies. The fundamental importance of practices of sharing with respect to the sociopolitical aspects of opening-up lends credence to this aspect. According to Lerman, Miyagawa, and Margulies (2008), open sharing of knowledge is at the heart of the academic process and becomes a customary practice in education at all levels. Hylen (2006) points out that the open sharing of research results and educational materials is essential, otherwise the traditional academic values will be increasingly marginalized by market forces. In the OER movement, education systems face the greatest challenges of breaking the aversion to openness (Torres, 2013). The author argues that this bias towards change and rejection of openness may lead to obsoleteness; with the closed educational content being a proof of lack of innovation, lack of quality and lack of commitment to sharing knowledge with everyone. Researchers have also indicated a lack of sharing culture in educational institutions (Kim \& Ju, 2014; Ehlers, 2011). According to Mckerlich, Ives, and McGreal (2013), one of the main issues that inhibit sharing and openness in higher education is intellectual property. A report (Falconer, McGill, Littlejohn, \& Boursinou, 2013) on a survey of OER initiatives from 12 countries mentioned investment in openness as one of the major challenges.

\section{Openness and Sharing in the Context of Distance Education}

Open education movement reflects "an affinity with distance education" as both address wider access to educational opportunities (Knox, 2013a, p. 22). Openness was also enabled by further developments in distance teaching-learning (Peter \& Deimann, 2013). Open learning and distance education represent approaches that focus on opening access to education and training provision, freeing learners from the constraints of time and place, and offering flexible learning opportunities for individuals and groups of learners (D’Antoni, 2009). Open universities and distance education institutions play a key role in providing education to a variety of learners across geographical, social, and economic barriers, especially in a developing country like India. India has one of the largest distance education systems in the world with one National Open University and 14 state open universities, and more than 200 distance education providers (University Grants Commission, n.d.). The use of open and distance learning to expand access to underserved populations has been critical to the growth of open education in both developing and developed nations (Olcott, 2013).

As mentioned by Feldstein (2008), "the commitment to open sharing of ideas provides a foundation for leveraging resources both within and among institutions, to strengthen the creation, transmission, and preservation of knowledge" (para. 2). Education globally is going through transformation towards a culture of openness, sharing, and collaboration. ODL institutions are also gradually adopting these practices to face the global challenges of changing educational needs, shrinking resources, and rising costs. In this context, knowledge sharing and openness among educators becomes all the more crucial. A number of research studies (Banzato, 2012; Reed, 2012; Masterman \& Wild, 2011; Kim \& Ju, 2008) explored the attitude of educators towards OER. Rolfe (2012) assessed staff awareness and behaviors surrounding OER with a focus on attitude to sharing resources. Veletsianos (2015) explored engagement of the academics in open practices and sharing. Allen and Seaman (2016) in their study on the use of OER by higher education faculty, found them to be interested in the "open" concept of OER. VillamejorMedoza (2013) explored openness at the UPOU (University of the Philippines Open University) based on 
four main parameters - open admissions, open curricula, distance education on a scale, and creation and use of OER. In the distance education scenario, openness is seen in the form of relatively flexible organizational structures, delivery and communication patterns, and the use of various technologies to support learning (UNESCO, 2002b).

Given that studies on openness and open sharing in distance education are scanty, there was a need for research studies discussing various aspects related to the culture of openness and sharing in ODL institutions, especially in India. It can be seen from the review of literature above, that most of the international research is focused on open educational resources and various issues related to technology, access, implementation, and use. Empirical research on the culture of openness and sharing in educational institutions, which is a prerequisite for the success of open education movement, is minimal. There was a strong need to investigate the perception, especially of the faculty, towards openness in open and distance learning institutions in India. This assumes significance at a time when the country is moving closer to establishing the platform for single-window national repository and teaching-learning (SWAYAM, i.e., Study Webs of Active-Learning for Young Aspiring Minds). The present study, therefore, examines the perception of the faculty towards openness in the mega open university in India. The study also investigates the intention and attitude of the faculty toward sharing of knowledge and learning resources in ODL institutions.

\section{Conceptual Framework}

At the core of open education lies the commitment to access and equity (Phelan, 2012). The underlying aim is to "solve longstanding educational problems of access and inclusion" (Knox, 2013b, p. 822), through "provision of access to learning opportunities to those who would not otherwise be able to obtain them" (Downes, 2011, para. 1), and who are "distributed by geography and income" (Edwards, 2015, p. 252). Openness and sharing are the underlying principles of Open Access, Open Education and OER movement (Villamejor-Mendoza, 2013; Pantò \& Comas-Quinn, 2012). Knox (2013b) discussed the notion of openness in education in the context of principles of individual freedom. He noted that openness in education has similarities with negative liberalism, which is mainly concerned with the emancipation from hierarchies of institutional control. OER must be considered in relation to a combination of political, social, and economic factors (Jones, 2015). As mentioned by Jones (2015) "openness in an open university is an ongoing dialogue between political objectives (often expressed via the state), pedagogic practices (embedded in the institution) and the available technologies" (p. 335). The wider framework for understanding the various aspects of openness in education can be viewed in terms of themes related to, content, university-based educational structures (institutions), pedagogy, learners, technology use, and related socio-economic factors. Several theoretical and empirical studies have highlighted issues such as:

- Diminishing of the traditional institutional structures (Jones, 2015; Knox, 2013b; Barber Donnelly, \& Rizvi2013);

- Downplay of the pedagogical functions of the university (Edwards, 2015; Knox, 2013b); 
- Learner-centered methods where learners can manage their own learning autonomously (Knox, 2013b, Phelan, 2012);

- Marketization and commodification of higher education and its subjects (Hall, 2015; Oliver, 2015; Jones, 2015; Macintosh, McGreal, \& Taylor 2011); and

- Costs associated with production, distribution, curation, and reuse of open resources (Jones, 2015; Pegler, 2012; Caswell Henson, Jensen, \& Wiley. 2008).

Edwards (2015) mentions that all forms of openness entail forms of closed-ness, which makes it important to consider what forms of openness are worthwhile and for whom. Moe (2015) remarks that open is often defined in economic terms of consumer cost and not in theoretical terms of remix or appropriation. It, therefore, becomes important to consider openness in the context of contemporary academic practices of institutions to address the barriers to participation (Oliver, 2015). Openness is a broad concept, debatable, and ever evolving; and, as mentioned by Tuomi (2013), has social, economic, cognitive and technical dimensions. In the present study, only the key notions, associated with openness in academic institutions, and relevant to the objectives of the study, were considered. These are:

- Open access and open publishing;

- Sharing and collaboration;

- Openness of resources;

- Creation and use of open educational resources; and

- Open and collaborative pedagogy.

The key underlying concepts related to knowledge sharing and openness were synthesized to formulate the conceptual framework to guide the present research study. The aim was to provide an understanding of the faculty perception of openness and their attitude to sharing in an ODL institution. The faculty perception of openness was analyzed in terms of 12 dimensions mentioned below:

- Belief in open education;

- Idea of knowledge as a public good;

- Willingness to share and collaborate;

- Attitude towards sharing;

- Recognition of benefits of sharing (both personal and institutional);

- Awareness of copyright permissions;

- Knowledge of creative commons licensing; 
- The interest in providing courses free;

- Stance on attribution and authorship;

- Creation and use of OER;

- Willingness to make a resource open; and

- $\quad$ Training requirements.

The present study investigated the faculty perception of openness and attitude towards sharing of knowledge and learning resources in the National Open University in India. The results may facilitate future implementation of open educational practices, in ODL institutions in India in particular, and in other contexts in general.

\section{Objectives of the Study}

The main objectives of the study were:

- To identify the perception of the faculty, of the national open university in India, about openness in education.

- To study the attitude of the faculty, of the national open university in India, towards sharing of knowledge and learning resources.

- To ascertain the willingness of the faculty of the national open university to share knowledge and learning resources.

In view of the above-mentioned objectives, the present study addresses the following research questions:

- What is the perception of the faculty in the national open university in India about openness in education?

- Is the faculty of the national open university engaged in the sharing of knowledge and learning resources?

- What is the willingness of the faculty in the national open university towards sharing of knowledge and learning resources?

- What is the attitude of the faculty in the national open university towards sharing of knowledge and learning resources? 


\section{Methodology}

In the present study, a positivist paradigm was used as it relies on quantitative data and the focus is on the objectivity of the research process. The methodology is descriptive, and the survey method was adopted to gather information regarding the perception of the faculty towards openness and sharing. The study involved the faculty (teachers and academics) of Indira Gandhi National Open University (IGNOU), the only national open university in India, which had a cumulative enrolment of above three million incountry and overseas students, studying through more than three thousand study centers.

\section{Sample}

The data for the study were gathered from the teachers and academics of IGNOU at its main campus, New Delhi, using the survey method. At the time of the study, there were 315 full-time faculty members (teachers and academics) at the main campus of the Indira Gandhi National Open University, New Delhi, in 21 schools of studies and some academic divisions. The survey was conducted by administering the questionnaire in person to the faculty members (and also sent by e-mail). This approach was preferred to ensure unbiased and high participation. The questionnaire was handed in person to the faculty members, of which 70 were returned, and 69 filled in questionnaires completed in all respects were considered for further analysis.

\section{Survey Instrument}

A structured questionnaire and an attitude scale were used in the survey. The development of the instruments was guided by the relevant literature on OER and the aspects of openness. The survey questionnaire had four subsets:

i) Demographics (6 items),

ii) Creation of learning resources (2 items),

iii) Perception about openness (11 items), and

iv) Intention towards sharing of knowledge and learning resources (5 items).

The Attitude Scale on attitude towards sharing among faculty members had 8 items.

The questionnaire consisted of multiple choice, ranking, and opinion questions. The face and content validity of the questionnaire were established through review by eight subject experts in educational technology and OER in higher education institutions in India. Based on their suggestions and feedback, required modifications were made to the questionnaire before employing it for data collection.

The responses to questions regarding the perception (11 items) and intention (5 items) were measured on a 3-point scale having "1" (as Yes), “2” (as No), and "3" (as Not Sure). The scale used for attitude had 8 items measured on a 5-point Likert scale ranging from 1 (Strongly Disagree) to 5 (Strongly Agree). The reliability of the scales was assessed using Cronbach's alpha. The Cronbach's alpha level of attitude scale was found to be 0.89 , indicating the high internal consistency of the items. The internal consistency for 
perception and intention scales was found to be acceptable with Cronbach's alpha values of 0.70 and 0.73 respectively. The high value of Cronbach's alpha indicated a high level of internal consistency.

\section{Data Collection}

The questionnaire and the attitude scale were administered personally to the faculty and through e-mail. Complete responses were received from 69 faculty members and academics of the university. The data were collected during November to December 2015.

\section{Data Analysis}

The gathered data were coded and transferred to SPSS to carry out further analysis. The responses thus collected were analyzed and interpreted based on the objectives of the study. Using SPSS, quantitative analysis was carried out and the results were tabulated. Personal data of the participants, their subject area of interest and types of learning resources created were calculated as frequency and percentage. The analysis of faculty members' perception towards openness, intention to share (Yes/ No/ Not sure scale); and the attitude to sharing (5-point Likert scale) involved calculating frequencies and percentages of the level of agreement and disagreement of the respondents. The findings of the study are presented in the following sections.

\section{Results}

\section{Participant Demographics}

Out of the 70 questionnaires administered, 69 completed responses were considered. As shown in Table 1, out of the 69 respondents, $53.6 \%(n=37)$ of the respondents were females; $40.6 \%(n=28)$ were associate professors; $29 \%(n=20)$ were over 46 years of age, and $55 \%(n=38)$ had work experience of 6-15 years in distance education.

Table 1

Demographic Profile of the Respondents

\begin{tabular}{llcc}
\hline Demographic status & \multicolumn{1}{c}{ Items } & $\mathrm{n}$ & $\%$ \\
\hline Professional Group & Professor & 7 & $10.1 \%$ \\
& Associate & 28 & $40.6 \%$ \\
& Professor & & \\
& Assistant & 22 & $31.9 \%$ \\
& Professor & & \\
& Other & 12 & $17.4 \%$ \\
Age & 25 years and under & 0 & $0.0 \%$ \\
& 26-35 years & 15 & $21.7 \%$ \\
Experience & O-45 years & 34 & $49.3 \%$ \\
& Over 46 years & 20 & $29.0 \%$ \\
& 1-5 years & 11 & $15.9 \%$ \\
& 6-10 years & 25 & $36.2 \%$ \\
& 11-15 years & 13 & $18.8 \%$ \\
& 16-20 years & 8 & $11.6 \%$
\end{tabular}




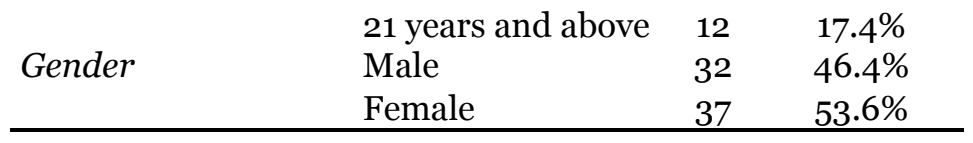

\section{Subject Area of Interest}

The respondents were asked about the subject areas they were interested in for the creation and use of learning resources. As shown in Table 2, the academics were from a wide range of subject areas - Sciences (30.4\%), Education (29\%), Social Sciences (24.6\%), and Arts, Language, and History (15.9\%).

Table 2

Subject Area of the Respondents

\begin{tabular}{lcc}
\hline \multicolumn{1}{c}{ Subject areas } & $\mathrm{N}$ & $\%$ \\
\hline Arts, Languages, and History & 11 & $15.9 \%$ \\
Mathematics, Computing, and & 6 & $8.7 \%$ \\
Engineering & & \\
Sciences and Environmental & 21 & $30.4 \%$ \\
Sciences (including Geography) & & \\
Health and Medicine & 8 & $11.6 \%$ \\
Social Sciences & 17 & $24.6 \%$ \\
Education & 20 & $29.0 \%$ \\
Business and Management & 4 & $5.8 \%$ \\
Others & 6 & $8.7 \%$ \\
\hline
\end{tabular}

\section{Types of Learning Resources Created}

The respondents were asked to indicate the type of learning resources they created or used during instruction. As shown in Table 3, textual materials were most common (92.8\%), followed by videos (75.4\%), images (53.6\%), and tutorials (52.2\%). Use of e-books and individual websites was much less preferred.

Table 3

Learning Resources Created

\begin{tabular}{lcc}
\hline \multicolumn{1}{c}{ Items } & $\mathrm{N}$ & $\%$ \\
\hline Textual materials & 64 & $92.8 \%$ \\
Videos & 52 & $75.4 \%$ \\
Images & 37 & $53.6 \%$ \\
Tutorials & 36 & $52.2 \%$ \\
Audio podcasts & 25 & $37.7 \%$ \\
Pre-recorded Lectures & 20 & $29.0 \%$ \\
E-books & 17 & $24.6 \%$ \\
Quizzes & 16 & $23.2 \%$ \\
Individual websites & 13 & $18.84 \%$ \\
\hline
\end{tabular}

\section{Perception Towards Openness}

The respondents were asked to rate their perception about openness in academic institutions on a scale where "1"= Yes, "2" = No and " 3 " = Not Sure. The responses were gathered in terms of eleven parameters 
viz., i) idea of knowledge as a public good, ii) making the program and courses available free, iii) providing learning resources freely and openly, vi) reaching a wider audience through OER, v) credit for the author or creator, vi) awareness of open licenses, vii) concern about intellectual property rights (IPR) and copyright permissions, viii) use of open source tools, ix) training for creation and use of OER, $\mathrm{x}$ ) use of collaborative pedagogical approaches in teaching and learning, and xi) ease of customization of OER (Figure 1).

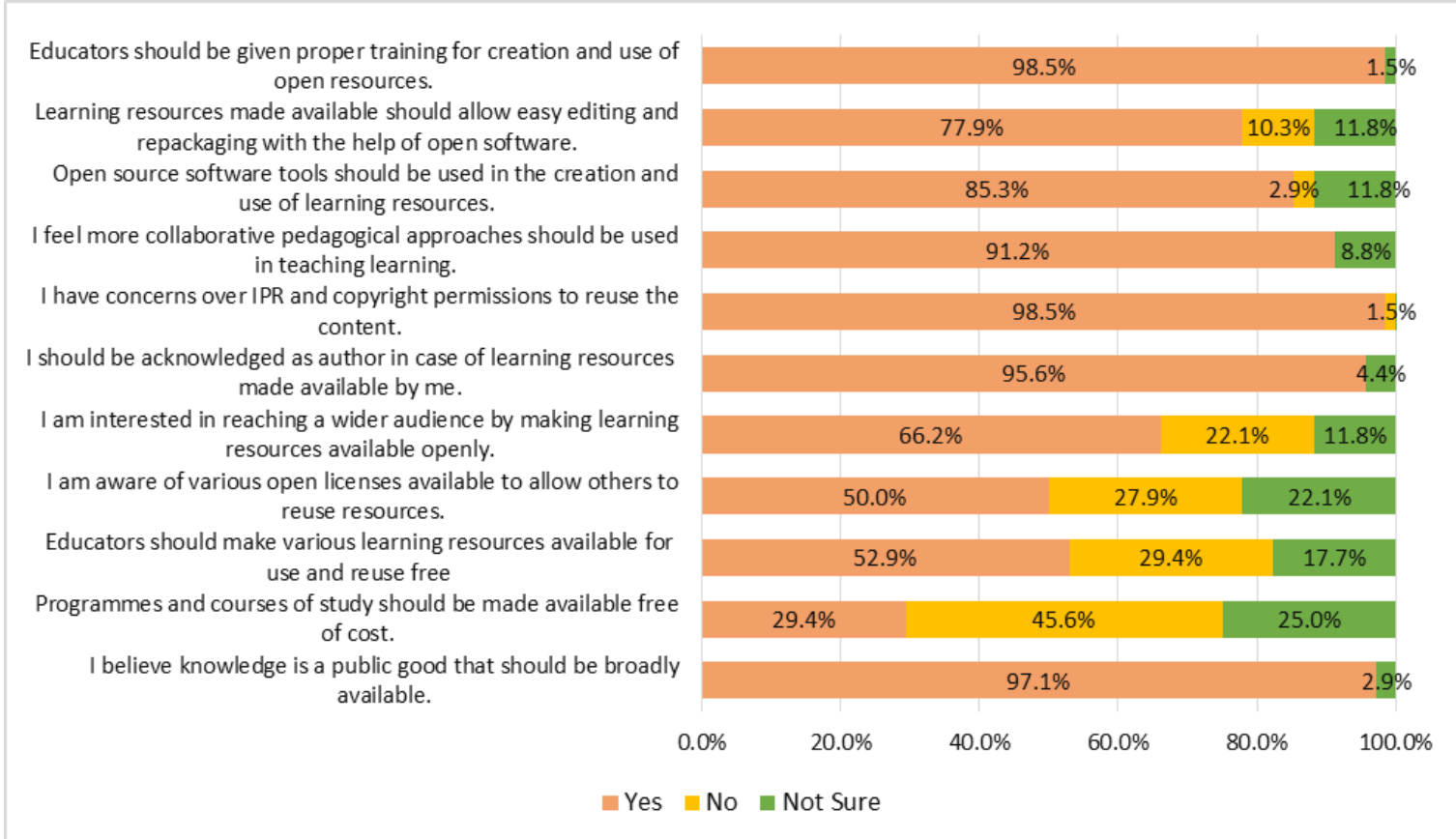

Figure 1. Perceptions towards openness.

As shown in Figure 1, 98.5\% respondents expressed a strong need for proper training (i.e., specific training related to OER, Copyright, IPR, etc.) in the creation and use of OER, and an equal percentage of respondents were concerned about IPR and copyright permissions to reuse the content. This was followed by the recognition that knowledge is a public good that should be made broadly available (97.1\%), desire to be acknowledged as an author for the educational resources made available by them (95.6\%), and inclination towards the use of collaborative pedagogical approaches in instruction (91.2\%). The results showed that while $52.9 \%$ were positively inclined towards making learning resources available free of cost, a large percentage $(70.6 \%)$ were not in favor of providing programs and courses of study free of cost to the students.

\section{Intention to Share Knowledge and Learning Resources}

The respondents were asked to indicate their intention to share knowledge and learning resources on a Yes/No/Not Sure scale (Figure 2). The majority of the respondents (92.7\%) indicated a positive inclination towards sharing of knowledge and learning materials among the faculty. A total of $91.2 \%$ respondents felt that sharing of knowledge and teaching resources will be useful in research and teaching activities, and a large number of respondents (79.4\%) indicated a willingness to share learning resources they developed. 


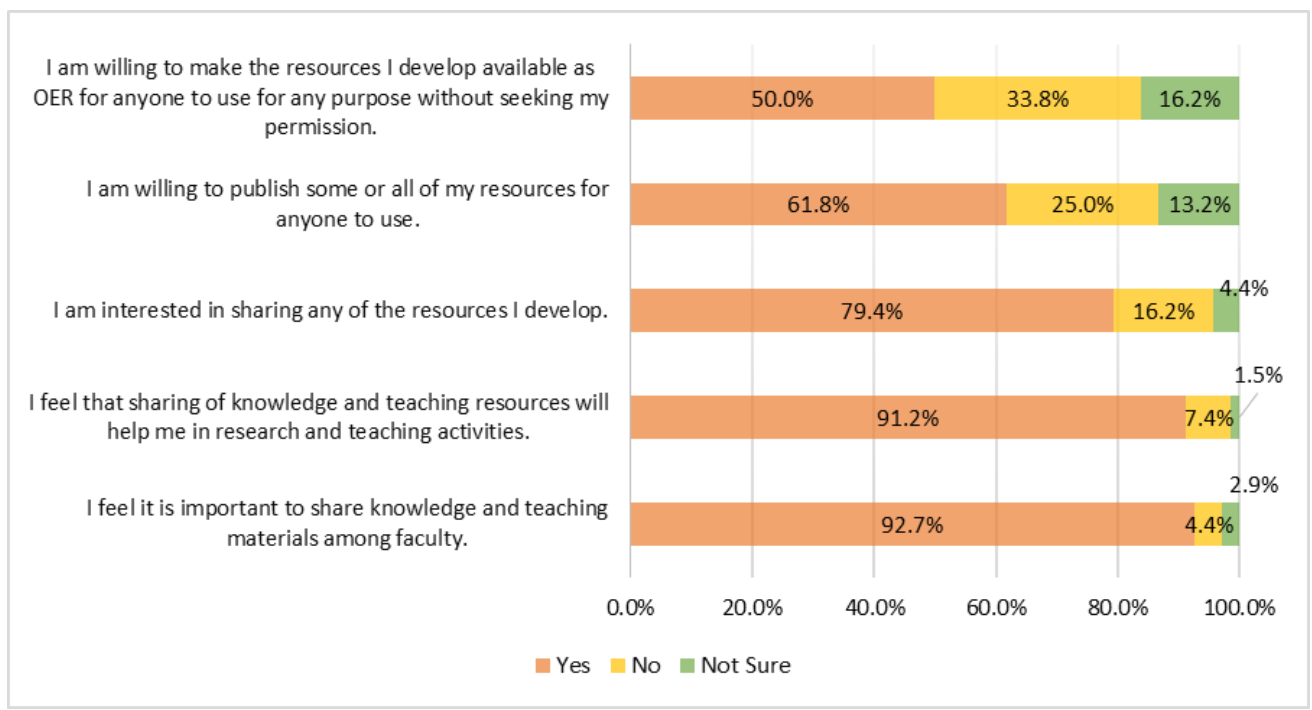

Figure 2. Intention to share knowledge and learning resources.

\section{Attitude Towards Sharing of Knowledge and Learning Resources}

An attempt was made to assess the attitude of the academics towards sharing of knowledge and learning resources. The respondents were asked to identify and rate a list of 8 statements on a 5-point Likert scale (where " 1 " = strongly disagree and " $5 "=$ strongly agree). The mean attitude score for the sample $(n=69)$ was calculated at 4.50 indicating that the majority of the respondents had a strong positive attitude towards the items rated (Table 4). The standard deviation ranged from 0.581 to 0.782 . The attitude measure also demonstrated good internal consistency with the Cronbach's alpha coefficient of o.89. It may be noted that the strongest favorable attitude statements concerned with the reputation of an educator, the reputation of the institution, and sharing leading to professional development and better performance, though pathways to innovation and enhancement of professional efficiency were indicated as "strongly agree" at above $50 \%$ of agreement.

Table 3

Attitude Towards Sharing of Knowledge and Learning Resources

\begin{tabular}{|c|c|c|c|c|c|c|c|c|}
\hline $\begin{array}{c}\text { S } \\
\text { No }\end{array}$ & Statement & $\begin{array}{c}\text { Strongly } \\
\text { agree }\end{array}$ & Agree & Neutral & Disagree & $\begin{array}{l}\text { Strongly } \\
\text { disagree }\end{array}$ & Mean & SD \\
\hline 1. & $\begin{array}{l}\text { Sharing of resources and knowledge } \\
\text { enhances the reputation of an educator. }\end{array}$ & $64.7 \%$ & $30.9 \%$ & $1.5 \%$ & $2.9 \%$ & $0.0 \%$ & 4.57 & 0.68 \\
\hline 2. & $\begin{array}{l}\text { Sharing of resources and knowledge is } \\
\text { essential in today's competitive } \\
\text { environment. }\end{array}$ & $61.8 \%$ & $33.8 \%$ & $4.4 \%$ & $0.0 \%$ & $0.0 \%$ & 4.57 & 0.58 \\
\hline 3. & $\begin{array}{l}\text { Sharing of resources and knowledge } \\
\text { enhances the reputation of the institution. }\end{array}$ & $61.8 \%$ & $33.8 \%$ & $2.9 \%$ & $1.5 \%$ & $0.0 \%$ & 4.56 & 0.63 \\
\hline
\end{tabular}




\begin{tabular}{|c|c|c|c|c|c|c|c|c|}
\hline 4. & $\begin{array}{l}\text { The sharing of resources amongst the } \\
\text { educators should be encouraged at the } \\
\text { institutional level. }\end{array}$ & $60.29 \%$ & $36.8 \%$ & $0.0 \%$ & $2.9 \%$ & $0.0 \%$ & 4.54 & 0.66 \\
\hline 5. & $\begin{array}{l}\text { Sharing of knowledge and resources is in line } \\
\text { with the academic traditions. }\end{array}$ & $58.82 \%$ & $36.8 \%$ & $2.9 \%$ & $1.5 \%$ & $0.0 \%$ & 4.53 & 0.63 \\
\hline 6. & $\begin{array}{l}\text { Sharing of resources and knowledge leads to } \\
\text { professional development and better } \\
\text { performance. }\end{array}$ & $61.8 \%$ & $29.4 \%$ & $4.4 \%$ & $4.4 \%$ & $0.0 \%$ & 4.49 & 0.78 \\
\hline 7. & $\begin{array}{l}\text { Sharing of resources and knowledge leads to } \\
\text { innovation in pedagogy. }\end{array}$ & $58.9 \%$ & $29.4 \%$ & $10.3 \%$ & $1.5 \%$ & $0.0 \%$ & 4.46 & 0.74 \\
\hline 8. & $\begin{array}{l}\text { Sharing of resources and knowledge } \\
\text { enhances the effectiveness and efficiency of } \\
\text { the educators. }\end{array}$ & $57.4 \%$ & $33.8 \%$ & $4.4 \%$ & $4.4 \%$ & $0.0 \%$ & 4.44 & 0.78 \\
\hline
\end{tabular}

\section{Discussion and Conclusion}

The aim of this study was to understand the perception of teachers and academics in an open and distance learning institution towards openness and sharing, as these are essential elements of the open educational practices that the educational world globally is moving towards. The present study focused on three key aspects related to openness in education - perception towards openness, willingness to share, and attitude towards sharing. The findings of the study are discussed in relation to the existing relevant research studies, wherever deemed appropriate.

The study revealed that textual materials were the most commonly created learning resources (at 92.75\%), followed by videos $(75.4 \%)$, images (53.6\%), and tutorials $(52.2 \%)$. The findings suggest that the faculty generally had a positive inclination towards sharing of knowledge and learning resources and believed that the learning resources should be made available free of cost to all.

The study analyzed the perception of the educators towards openness in education based on 11 parameters mentioned above. These parameters covered various aspects related to the implementation of openness in higher education institutions. Several researchers have discussed the altruistic motivations of openness and sharing in keeping with the academic traditions (Kursun, Cagiltay \& Can, 2014; Awang, Ismail \& Kareem, 2013; McNamara, 2012; Pena, 2009; Downes, 2007; OECD, 2007; Hylén, 2006). Lerman et al. (2008) noted that open sharing of knowledge is at the heart of the academic process. It is widely believed that world's knowledge is a public good to be shared, used, and reused (Olcott, 2013; Torres, 2013; McNamara, 2012; Jones, 2015). This idea is central to the OER movement (Smith \& Casserly, 2006). The findings of the present study indicate that the majority of the respondents (97.1\%) believed that knowledge is a public good and should be widely available. The findings are consistent with the findings of a study conducted by Rolfe (2012) in a UK University, where a strong belief in open education emerged as a major driving factor, and 52.9\% of the respondents believed that educators should make various learning resources available for use and reuse for free. However, the respondents in the present study were not in favor of making the academic programs and courses available free of cost, with only $29.4 \%$ of respondents supporting it. This could be attributed to the culture and belief among Indian educators generally that anything which is available for free might not be valued by the learners (Chavan, 2012); and also that institutions need to earn from student fees for their sustenance. 
The results highlight a strong need for proper training (i.e., specific training related to copyright, IPR, OER, etc.) in the creation and use of OER. This is also consistent with previous research findings (Kursun et al., 2014; Okonkwo, 2012; Clements \& Pawlowski, 2012). In the case of the present study, the findings indicated that the majority of the respondents (98.5\%) were concerned about the IPR and copyright permissions to reuse the content. Previous research has indicated that there is considerable ambiguity among the educators regarding copyright permissions and that they have concerns about protecting their intellectual property rights (de Hart, Chetty, \& Archer, 2015; Kursun et al., 2014; Brent, Gibbs, \& Gruszczynska, 2012). Only 50\% of the respondents were aware of the available licensing options to enable reuse of the existing resources. Similar results were reported by Veletsinos (2015), who in his case study on open and sharing practices at a North American university, found a lack of understanding of the concept of Creative Commons licensing among the faculty.

Other researchers (Pantò \& Comas-Quinn, 2013; Pena, 2009) have emphasized the need for increased awareness of copyright issues and appropriate training on legal, technical, and operational issues in educational institutions. The study by Rolfe (2012) also revealed staff requirements for technical assistance and clarity over copyright. The issues of attribution, authorship, and ownership are complex tasks, especially while remixing and reusing content, and the issues of language and context make the straightforward reuse of resources difficult (Amiel, 2013). The findings of the present study suggest that a large number of respondents (95.6\%) desired proper attribution to the resources made available. The results also indicate that $\mathbf{9 1 . 2 \%}$ respondents favored the use of collaborative pedagogical approaches in teaching and learning. According to Chen and Panda (2013), making OER easier for selection, revision, and use, as well as making it suitable to the context are key issues in OER utilization. The study also highlighted the need for enabling easy remixing and use of the available learning resources.

The study further analyzed the willingness of the faculty to share knowledge and learning resources (Figure 2). The results indicated that a large percentage of faculty members (91\%) recognized that sharing of knowledge and learning resources is helpful in research and teaching activities. The respondents (93\%) were aware of the importance of sharing within the faculty. Previous research has often highlighted the reluctance of faculty towards sharing their resources openly as OER (de Hart et al., 2015; Rolfe, 2012). The results revealed that a large number of respondents (79\%) were interested in sharing the resources they had developed and 50\% were willing to make the developed resources available as OER without the requirement to seek their permission for use or re-use. This strengthens the findings about faculty perception towards openness - that they are interested in sharing the learning resources but not their academic programs and courses for free.

The study also investigated the attitude of the faculty towards sharing of knowledge and learning resources. The attitude scores reflected that the respondents had significantly positive inclination towards sharing of knowledge and learning resources, sharing of knowledge and resources enhances the reputation of the educator and the institution; sharing of knowledge and resources is essential to meet competition, and it should be encouraged at the institutional level. These findings are in alignment with the findings reported by Rolfe (2012), where faculty's belief in the ability of OER to enhance individual and institutional reputation emerged as a major motivating factor. Based on detailed analysis of evaluation reports of MIT, Hodgkinson-Williams (2010) mentioned that the opening of the courses by 
MIT led to an enhanced public image and attracted learners from all over the world. Moreover, in the present study, $29 \%$ of the faculty reported the positive influence of MIT OCW on their professional standing.

The above findings are valuable and indicative of institutional and faculty preparedness in terms of policy, provision, preparedness, and training for effective utilization of OER for open and distance learning in general and the national open university in particular. The faculty suggestions are in order in the sense that: there is a need for institutions to put in place OER policy (consistent with ICT, IPR, copyright, and plagiarism policies); there is a need for effective institutional system and provision for OER and sharing of resources; and a strong continuing professional development regime for ICT, OER, MOOCs, etc., needs to be in place. The findings need to be read in relation to further research on student perception and use of OER.

\section{Limitations of the Study}

The major limitation of the study is that quantitative survey method was used to assess the perception and attitude of the faculty. Though a questionnaire always has limitations as compared to qualitative methods such as interview, it makes possible the inclusion of a greater number of participants in the survey. Another limitation is that the questionnaire did not have any open-ended question which could have provided more profound insight into the complex issue of openness among the educators. Further, a large number of institutions and faculty can be sampled for the globalization of the findings.

\section{References}

Allen, I., \& Seaman, J. (2016). Opening the textbook: Educational resources in U.S. higher education, 2015-16. Report published by Babson Survey Research Group. Retrieved from https://www.onlinelearningsurvey.com/reports/openingthetextbook2016.pdf

Amiel, T. (2013). Identifying barriers to the remix of translated open educational resources. International Review of Research in Open and Distance Learning, 14(1), 126-144. Retrieved from http://www.irrodl.org/index.php/irrodl/article/view/1351

Awang, M., Ismail, R., \& Kareem, O. A. (2013). Socially constructed knowledge: An inquiry into sharing activity among teachers. International Journal of Education and Research, 1(9).

Banzato, M. (2012). Barriers to teacher educators seeking, creating and sharing open educational resources: an empirical study of the use of OER in education in Italy. Paper presented at the 15th International Conference on Interactive Collaborative Learning, Villach.

Barber, M., Donnelly, K., \& Rizvi, S. (2013). An avalanche is coming: Higher education and the revolution ahead. London: Institute for Public Policy Research. Retrieved from 
http://www.ippr.org/images/media/files/publication/2013/04/avalancheiscoming Mar2013 10432.pdf

Baraniuk, R. G. (2008). Challenges and opportunities for the open education movement: A connexions case study. In T. Iiyoshi \& M. S. Vijay Kumar (Eds.), Opening up education: The collective advancement of education through open technology, open content, and open knowledge (pp. 229-246). Cambridge, MA: MIT Press.

Bayne, S., Knox, J., \& Ross, J. (2015). Open education: The need for a critical approach. Learning, Media and Technology, $40(3), 247-250$. Retrieved from http://dx.doi.org/10.1080/17439884.2015.1065272

Brent, I., Gibbs, G. R., \& Gruszczynska, A. K. (2013). Defining openness: Updating the concept of "open" for a connected world. JIME. Retrieved from http://jime.open.ac.uk/2012/05

Butcher, N. (2011). A basic guide to open educational resources (OER). Vancouver: UNESCO \& COL. Retrieved from http://www.col.org/PublicationDocuments/Basic-Guide-To-OER.pdf

Cape Town Open Education Declaration. (2007). Cape Town open education declaration: Unlocking the promise of open educational resources. Cape Town: Open Society Institute. Retrieved from http://www.capetowndeclaration.org/read-the-declaration

Caswell, T., Henson, S., Jensen, M., \& Wiley, D. (2008). Open educational resources: Enabling universal education. International Review of Research in Open and Distance Learning, 9(1), 1-11. Retrieved from http://www.irrodl.org/index.php/irrodl/article/view/469/1009

Committee for Economic Development. (2009). Harnessing openness to improve research, teaching and learning in higher education. Washington, DC: Committee for Economic Development. Retrieved from https://www.ced.org/pdf/Harnessing-Openness-to-Improve-Research-Teaching-andLearning-in-Higher-Education.pdf

Chavan, M. (2012). Changing times demand change. Journal of Indian Education, 28(2), 5-19. Retrieved from http://www.ncert.nic.in/publication/journals/pdf files/JIE_AUG2012.pdf

Chen, Q., \& Panda, S. (2013). Needs for and utilization of OER in distance education: A Chinese survey. Educational Media International, 5o(2), 77-92.

Cheng, T. L. (2013). Towards a new era in open education: from the "classical" to the "inventive" world of digital openness. Journal of Educational Research and Studies, 1(6), 56-66. Retrieved from https://www.peakjournals.org/sub-journals-JERS.html

Clements, K. I., \& Pawlowski, J. M. (2012). User-oriented quality for OER: Understanding teachers' views on re-use, quality, and trust. Journal of Computer Assisted Learning, 28(1), 4-14. Retrieved from http://dx.doi.org10.1111/j.1365-2729.2011.00450.x 
Conole, G. (2010). A framework for technological intervention. e4innovation. Retrieved from http://e4innovation.com/?p 364

Dalsgaard, C., \& Thestrup K. (2015). Dimensions of openness: Beyond the course as an open format in online education. International Review of Research in Open and Distributed Learning, 16(6), 78-97. Retrieved from http://www.irrodl.org/index.php/irrodl/article/view/2146/3555

D’Antoni, S. (2009). Open educational resources: Reviewing initiatives and issues. Open Learning, 24(1), 3-10. Retrieved from http://www.tandfonline.com/doi/pdf/10.1080/02680510802625443

Daniel, J. (2007). What is an Open University? Address delivered at Tamil Nadu Open University, Convocation. Retrieved from http://oasis.col.org/bitstream/handle/11599/1516/2007 DanielJ WhatisOpenUniversity Trans cript.pdf?sequence $=1$

de Hart, K., Chetty, Y., \& Archer, E. (2015). Uptake of OER by staff in distance education in South Africa. International Review of Research in Open and Distributed Learning, 16(2). Retrieved from http://www.irrodl.org/index.php/irrodl/article/view/2047

Deimann, M., \& Sloep, P. (2013). How does open education work?, In A. Meiszner \& L. Squires (Eds.) Openness and education: Advances in digital education and lifelong learning (pp. 1-23). London: Emerald.

Downes, S. (2007). Models for sustainable open educational resources. Interdisciplinary Journal of Knowledge and Learning Objects, 3, 29-44.

Downes, S. (2011, March 17 $\left.7^{\text {th }}\right)$. Five key questions. [Weblog Comment]. Retrieved from http://halfanhour.blogspot.com/2011/o3/five-key-questions.html

Edwards, R. (2015). Knowledge infrastructures and the inscrutability of openness in education. Learning, Media and Technology, 4o(3), 251-264.

Ehlers, U.-D. (2011). From open educational resources to open educational practices. eLearning Papers, 23. Retrieved from http://elearningpapers.eu/en/download/file/fid/22240

Falconer, I., McGill L., Littlejohn A., \& Boursinou E. (2013). Overview and analysis of practices with open educational resources in adult education in Europe. European Commission JRC - Institute for Prospective Technological Studies, European commission. Luxembourg: EU Publications Office. Retrieved from http://ftp.jrc.es/EURdoc/JRC85471.pdf

Feldstein, M. (2008, October 30). EDUCAUSE openness constituent group. Retrieved from http://mfeldstein.com/educause-openness-constituent-group

Geser, G. (2007). Open educational practices and resources OLCOS Roadmap 2012. Austria: OLCOS Project. Retrieved from http://www.olcos.org/cms/upload/docs/olcos roadmap.pdf 
Hall, R. (2015). For a political economy of massive open online courses. Learning, Media and Technology, 4o(3), 265-286.

Hodgkinson-Williams, C. (2010). Benefits and challenges of OER for higher education institutions. Retrieved from http://www.oerafrica.org/resource/benefits-and-challenges-oer-higher-education

Hodgkinson-Williams, C., \& Gray, E. (2009). Degrees of openness: The emergence of open educational resources at the University of Cape Town. International Journal of Education and Development using Information and Communication Technology, 5(5), 101-116.

Hug, T. (2014). Education for all revisited: On concepts of sharing in the open educational resources (OER) movement. Seminar.net, 1O(1). Retrieved from http://www.seminar.net/images/stories/vol10-issue1/Theo Hug Education-for-all Essay.pdf

Hylén, J. (2006). Open educational resources: Opportunities and challenges. Paris: OECD-CERI. Retrieved from http://www.oecd.org/edu/ceri/37351085.pdf

Iiyoshi, T., \& Vijay Kumar, M.S. (Eds.). (2008). Opening up education: The collective advancement of education through open technology, open content, and open knowledge. Cambridge: The MIT Press.

Jones, C. (2015). Openness, technologies, business models and austerity. Learning, Media and Technology, 4o(3), 328-349.

Kim, S., \& Ju, B. (2008). An analysis of faculty perceptions: Attitudes toward KS and collaboration in an academic institution. Library and Information Science Research, 30, 282-290.

Knox, J. (2013a). The limitations of access alone: Moving towards open processes in education technology. Open Praxis, 5(1), 21-29.

Knox, J (2013b). Five critiques of the open educational resources movement. Teaching in Higher Education, 18(8), 821-832.

Kursun, E., Cagiltay, K., \& Can, G. (2014). An investigation of faculty perspectives on barriers, incentives, and benefits of the OER movement in Turkey. International Review of Research in Open and Distributed Learning, 16(6), 15-32. Retrieved from http://www.irrodl.org/index.php/irrodl/article/view/1914

Lane, A. (2009). The impact of openness on bridging educational digital divides. International Review of Research in Open and Distance Learning, $10(5)$. Retrieved from http://www.irrodl.org/index.php/irrodl/article/view/637/1396

Lerman, S.R., Miyagawa, S., \& Margulies, A. H. (2008). OpenCourseWare: Building a culture of sharing. In T. Iiyoshi \& M.S. Vijay Kumar (Eds.) Opening up education. The collective advancement of 
education through open technology, open content, and open knowledge (pp. 213-227). Cambridge: The MIT Press.

Macintosh, W., McGreal, R., \& Taylor, J. (2011). Open education resources (OER) for assessment and credit for students project: Towards a logic model and plan for action. Athabasca University: Athabasca. Retrieved from http://auspace.athabascau.ca:8080/dspace/handle/2149/3039

Masterman, L., \& Wild, J. (2011). OER impact study: Research report. JISC Open Education Resources Programme, Phase 2. University of Oxford. Retrieved from http://icde.org/filestore/Resources/Reports/OERImpactStudyResearchReport.pdf

McKerlich, R. C., Ives, C., \& McGreal, R. (2013). Measuring use and creation of open educational resources in higher education. International Review of Research in Open and Distance Learning, 14(4), 1-14.

McNamara, T. (2012). Open education: Emergence and identity. Retrieved from http://ohinstitute.org/external resources/pub/McNamara-OpenEd Emergence Identity-CC-by.pdf

Mishra S. (2012). Openness in education: Some reflections on MOOCs, OER and ODL. Keynote. Retrieved from http://www.col.org/resources/speeches/2012presentations/Pages/2012-11$\underline{14 . a s p x}$

Moe, R. (2015). OER as online edutainment resources: A critical look at open content, branded content, and how both affect the OER movement. Learning, Media and Technology, 4O(3), 350-364.

OECD. (2007). Giving knowledge for free: the emergence of open educational resources. Paris: OECD. Retrieved from http://www.oecd.org/edu/ceri/38654317.pdf

Okonkwo, C. (2012). A needs assessment of ODL educators to determine their effective use of open educational resources. International Review of Research in Open and Distance Learning, 13(4), 293-312. Retrieved from http://www.irrodl.org/index.php/irrodl/article/view/1316

Olakulehin, F.K., \& Singh, G. (2013). Widening access through openness in higher education in the developing world: A bourdieusian field analysis of experiences from the National Open University of Nigeria. Open Praxis, 5(1), 31-40.

Olcott, D. (2012). OER perspectives: Emerging issues for universities. Distance Education, 33(2), 283290. Retrieved from http://dx.doi.org/10.1080/01587919.2012.700561

Olcott, D. (2013). Access under siege: Are the gains of open education keeping pace with the growing barriers to university access? Open Praxis, 5(1), 15-20. Retrieved from http://openpraxis.org/index.php/OpenPraxis/article/view/14

Oliver, M. (2015). From openness to permeability: Reframing open education in terms of positive liberty in the enactment of academic practices. Learning, Media and Technology, 4O(3), 365-384. 
Pantò, E., \& Comas-Quinn, A. (2013). The challenge of open education. Journal of E-Learning and Knowledge Society, 9(1), 11-22. Retrieved from http://www.jelks.org/ojs/index.php/JeLKS EN/article/view/798

Pegler, C. (2012). Herzberg, hygiene and the motivation to reuse: Towards a three-factor theory to explain motivation to share and use OER. Journal of Interactive Media in Education 2012, 1(4). doi: http://dx.doi.org/10.5334/2012-04

Pena, H. (2009). Higher education: The success and challenges in open education resources (OER). Eprints in Library and Information Science (E-LIS). Retrieved from http://eprints.rclis.org/13743/1/pena.pdf

Peters, M. A. (2008). The history and emergent paradigm of open education. In M. A. Peters \& R. Britez. (Eds.) Open education and education for openness (pp. 3-16). Rotterdam \& Taipei: Sense Publishers.

Peter, S., \& Deimann, M. (2013). On the role of openness in education: A historical reconstruction. Open Praxis, 5(1), pp. 7-14.

Phelan, L. (2012). Politics, practices, and possibilities of open educational resources, Distance Education, 2(33), 279-282.

Reed, P. (2012). Awareness, attitudes and participation of teaching staff towards the open content movement in one university. Research in Learning Technology, 20. doi: 10.3402/rlt.v20io.18520

Rolfe, V. (2012). Open educational resources: Staff attitudes and awareness. Research in Learning Technology, 20, 1-13. doi:10.3402/rlt.v20io/14395

Schaffert, S., \& Geser, G. (2008). Open educational resources and practices. eLearning Papers, 7. Retrieved from http://www.elearningeuropa.info/files/media/media14907.pdf

Smith, M.S., \& Casserly, C.M. (2006). The promise of open educational resources. Change, 38(5), 8-17.

Tapscott, D., \& Ticoll, D. (2003). The naked corporation. New York: Free Press.

Torres, N. P. M. (2013). Embracing openness: The challenges of OER in Latin American education. Open Praxis, 5(1), 81-89. Retrieved from http://openpraxis.org/index.php/OpenPraxis/article/view/33

Tuomi, I. (2006). Open educational resources: What they are and why do they matter. Report prepared for the OECD. Retrieved from http://www.meaningprocessing.com/personalPages/tuomi/articles/OpenEducationalResources OECDreport.pdf

Tuomi, I. (2013). Open educational resources and the transformation of education. European Journal of Education, 48(1). Retrieved from http://onlinelibrary.wiley.com/doi/10.1111/ejed.12019/full 
University Grants Commission. (n.d.). Growth of ODL system in higher education. Retrieved from http://www.ugc.ac.in/deb/pdf/growthDEB.pdf

UNESCO. (2002a). Forum on the impact of open courseware for higher education in developing countries. Paris: UNESCO. Retrieved from http://unesdoc.unesco.org/images/o012/001285/128515e.pdf

UNESCO. (2002b). Open and distance learning: trends, policy and strategy considerations. Paris: UNESCO. Retrieved from http://unesdoc.unesco.org/images/o012/001284/128463e.pdf

UNESCO. (2014). How openness impacts on higher education: policy brief. Retrieved from http://iite.unesco.org/pics/publications/en/files/3214734.pdf

Veletsianos, G. (2015). A case study of scholars' open and sharing practices. Open Praxis, 7(3), 199-209. doi:10.5944/openpraxis.7.3.206

Villamejor-Mendoza, M. F. (2013). The openness of the university of the Philippines open university: Issues and prospects. Open Praxis, 5(2), 135-150. Retrieved from http://openpraxis.org/index.php/OpenPraxis/article/view/26

Wiley, D. (2006). Open source, openness, and higher Education. Innovate Journal of Online Education, $3(1)$.

Wiley, D. (2009). Defining ‘Open’ [Blog post]. Retrieved from http://opencontent.org/blog/archives/1123

Wiley, D. (2014). The access compromise and the $5^{\text {th }}$ R. [Blog post]. Retrieved from http://opencontent.org/blog/archives/3221

Wiley, D., \& Green, C. (2012). Why openness in education? In D. Oblinger (Ed.), Game changers: Education and information technologies (pp. 81-9). Washington, DC: Educause.

Wiley, D., \& Hilton, J., III. (2009). Openness, dynamic specialization, and the disaggregated future of higher education. International Review of Research in Open and Distance Learning, 10(5) 1-17. Retrieved from http://www.irrodl.org/index.php/irrodl/article/view/768/1415

Weller, M. (2011). The digital scholar: How technology is transforming scholarly practice. London, UK: Bloomsbury Academic.

Weller, M. (2012). The openness-creativity cycle in education: A perspective. Journal of Interactive Media in Education, 12(1), 2. Retrieved from http://oro.open.ac.uk/33296/1/219-1968-1-PB.pdf

Yuan, L., Macneill, S., \& Kraan, W. (2008). Open educational resources - opportunities and challenges for higher education. JISC CETIS. Retrieved from https://oerknowledgecloud.org/sites/oerknowledgecloud.org/files/OER_Briefing_Paper.pdf 
Yuan, L., \& Powell, S. (2013). MOOCs and open education: Implications for higher education. A white paper. United Kingdom: JISC-CETIS. Retrieved from http://publications.cetis.org.uk/2013/667

Athabasca

University

(c) 